\title{
Aplikasi Penyewaan Alat Laboratorium Fakultas Perikanan dan Ilmu Kelautan Universitas Papua
}

\author{
Marlinda Sanglise \\ Jurusan Teknik Informatika, Fakultas Teknik, Universitas Papua, Amban, Manokwari, Indonesia, 98314 \\ e-mail: m.sanglise@unipa.ac.id
}

\begin{abstract}
The Faculty of Fisheries and Marine Sciences (FPIK) is one of the Faculties at the University of Papua which has two majors namely, Aquatic Resources and Marine Sciences. Each department has a laboratory that can be rented by students, lecturers, and the general public. The large number of laboratory equipment often makes it difficult for laboratory managers to arrange loan data and return laboratory equipment. Most of the borrowing data is filed in the form of files which might be damaged if a disaster occurs, besides that the means to promote laboratory equipment rental services for the general public are still manual, by placing advertisements placed on the FPIK Walls, which are generally can be seen by students in the Faculty. Based on this condition, an application for leasing laboratory equipment was made in FPIK using Macromedia Dreamweaver 8 and PHP Mysql. With the existence of this application it can help each process of borrowing and returning laboratory equipment more effectively. Some features contained in this application include member registration, registration of loan forms, return forms, tool data, and transaction lists.
\end{abstract}

Keywords: Laboratory; Borrowing; Return; Macromedia Dreamweaver 8; MySQL

\section{Pendahuluan}

Dalam era Teknologi Informasi dan Komunikasi, Fakultas Perikanan dan Ilmu Kelautan (FPIK) Universitas Papua (Unipa) juga telah mulai menerapkan penggunaan teknologi dalam mengelola setiap kegiatannya. Salah satu bagian yang sudah mulai memanfaatkan teknologi informasi dan komunikasi adalah bagian laboratorium FPIK. Penggunaan ini meliputi pendaftaran member (anggota), transaksi peminjaman dan juga transaksi pengembalian peralatan laboratorium di FPIK. Dengan jumlah peralatan yang terbilang cukup banyak serta frekuensi peminjaman yang dilakukan hampir tiap hari, dimana rata-rata peminjaman alat sebulan bisa mencapai 40 alat, hal ini sering membuat para pegawai sulit untuk mengelola data transaksi, baik itu data jumlah alat yang dipinjam, rusak ataupun jumlah alat yang telah dikembalikan. Keadaan ini disebabkan karena proses peminjaman dan pengembalian dilakukan melalui sebuah pencatatan pada buku transaksi yang ada di laboratorium FPIK Unipa. Termasuk juga pengelolaan keuangan yang diperoleh dari biaya penyewaan alat laboratorium dan denda akibat keterlambatan pengembalian alat laboratorium. Selain itu juga, proses peminjaman masih dilakukan secara langsung, yaitu peminjam harus datang sendiri ke laboratorium untuk melakukan proses peminjaman dan pengembalian peralatan laboratorium. Sehingga terkadang alat yang dikembalikan oleh member telah rusak karena tidak ada proses pengecekan yang dilakukan oleh petugas laboratorium saat pengembalian. Hal inilah yang mendasari sehingga dibuatlah aplikasi peminjaman dan pengembalian alat laboratorium yang berbasis web menggunakan Macromedia Dreamweaver 8 dan MySQL. Dengan adanya aplikasi ini proses pendaftaran member dan proses peminjaman dapat dilakukan secara online yaitu peminjam cukup mendaftar dan meminjam secara online dan alat yang dipinjam akan diantar langsung ke alamat peminjam oleh petugas Laboratorium. Begitupun saat pengembalian alat cukup dilakukan secara online dan petugas laboratorium akan datang untuk memeriksa dan mengambil alat laboratorium yang dipinjam.

\section{Dasar Teori}

\subsection{Kajian Penelitian Relevan}

Pada tahun 2015, penelitian yang dilakukan oleh Nana Rukmana yang berjudul aplikasi peminjaman alat laboratorium untuk mahasiswa berbasis web di STIKes Dharma Husada Bandung. Aplikasi ini dibuat untuk membantu pihak Kampus STIKes dalam mengelola transaksi peminjaman alat laboratorium seperti EKG, Infus, Phantom, stetoscope dan lain-lain. Namun aplikasi yang 
dibuat hanya difokuskan pada proses peminjaman alat saja sedangkan untuk proses pengembaliannya tidak diproses. Sehingga dari segi keamanan alat dan stok yang tersedia susah untuk dideteksi melalui aplikasi ini.

Penelitian yang dilakukan oleh Aditya Bimo Prayogo dan Barka Satya (Bimo \& Barka, 2017) yang berjudul perancangan sistem informasi peminjaman alat laboratorium di Jurusan Teknik Geologi STTNAS Yogyakarta. Dalam penelitian ini aplikasi yang dibangun menggunakan VB.Net dan MySQL sebagai databasenya. Namun dalam aplikasi ini bersifat offline yaitu proses peminjaman harus dilakukan di laboratorium.

\subsection{Metode Pengumpulan Data}

1. Studi Pustaka

Membaca buku-buku referensi dan situs internet yang dapat dijadikan acuan untuk pembuatan aplikasi ini. Selain itu dilakukan juga penelusuran pustaka yang berhubungan dengan sistem informasi yang menyangkut proses dan alur yang terjadi pada sistem aplikasi ini.

2. Studi Lapangan.

Studi lapangan yang di lakukan adalah pengambila data pada Laboratorium Kelautan Universitas Papua, dari hasil studi lapangan ini penulis dapat melihat masalah yang akan di teliti dengan akurat.

3. Wawancara

Penulis melakukan proses wawancara pada Laboratorium Kelautan untuk memperoleh beberapa informasi di lapangan dalam menyangkut aliran sistem peminjaman yang berlaku, sistem denda, serta informasi lainnya yang penting digunakan untuk pembuatan aplikasi ini.

\subsection{Metode Pengembangan Sistem}

Metode pengembangan sistem yang digunakan dalam pembuatan aplikasi ini yaitu metode Waterfall, metode pengembangan sistem ini meliputi:

\section{Analisis Sistem}

Analisa yang dilakukan dalam proses pembuatan aplikasi yaitu dengan menganalisis proses penyewaan alat yang selama ini dilakukan di Laboratorium FPIK, mulai dari proses pendaftaran, peminjaman, pembayaran hingga pengembalian alat laboratorium. Hasil analisa inilah yang digunakan sebagai dasar dalam pembuatan aplikasi penyewaan.

2. Perancangan

Proses perancangan yang dilakukan oleh penulis adalah menyusun sebuah alur program yang akan diterapkan dalam aplikasi yang bertujuan untuk memudahkan sistem peminjaman, ataupun sistem pengembalian yang terjadi pada Laboratorium Kelautan. Alur program dirancang dengan menggunakan Data Flow Diagram (DFD), Entity Relationship Diagram (ERD).

3. Implementasi

Pembuatan source code dalam aplikasi ini menggunakan bahasa pemograman PHP. Sedangkan databasenya menggunakan MySQL.

4. Pengujian

Pengujian aplikasi ini dilakukan untuk menilai apakah aplikasi yang dibuat telah sesuai dengan permintaan user. Dalam hal ini, pengujian blackbox dilakukan oleh petugas laboratorium selaku admin, dan juga beberapa mahasiswa sebagai member. Selanjutnya pengujian juga dilakukan dengan menyebarkan kuesioner bagi bagi admin maupun member yang berasal dari kalangan mahasiswa, dosen, dan masyarakat umum.

\section{Analisa Dan Perancangan}

\subsection{Rancangan Diagram Konteks}

Berikut adalah gambar diagram konteks aplikasi penyewaan alat laboratorium FPIK,

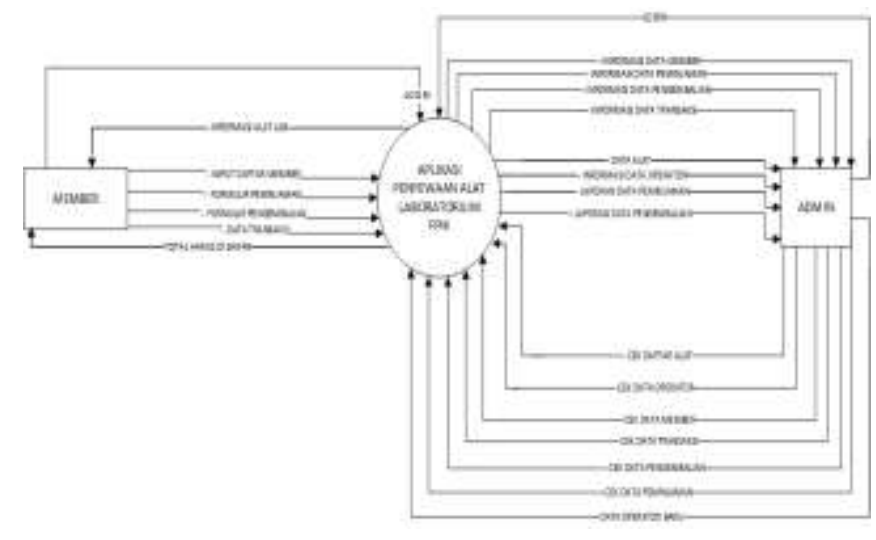

Gambar 1 Diagram Konteks

Dalam diagram konteks di atas, terlihat bahwa aplikasi penyewaan alat laboratorium ini memiliki dua buah entitas yaitu member dan 
admin. Bagi member terdapat empat arus data yang merupakan inputan ke dalam sistem yaitu data member, penginputan formulir peminjaman, formulir pengembalian, dan data transaksi. Sedangkan bagi admin terdapat tujuh arus data yang semuanya merupakan proses pengecekan data yang meliputi data alat, member, transaksi, pengembalian, dan peminjaman.

\subsection{Rancangan Data Flow Diagram (DFD)}

\subsubsection{DFD Level 1 Proses Input Data}

Berikut adalah DFD Level 1 Proses Input

Data dapat dilihat pada gambar berikut:

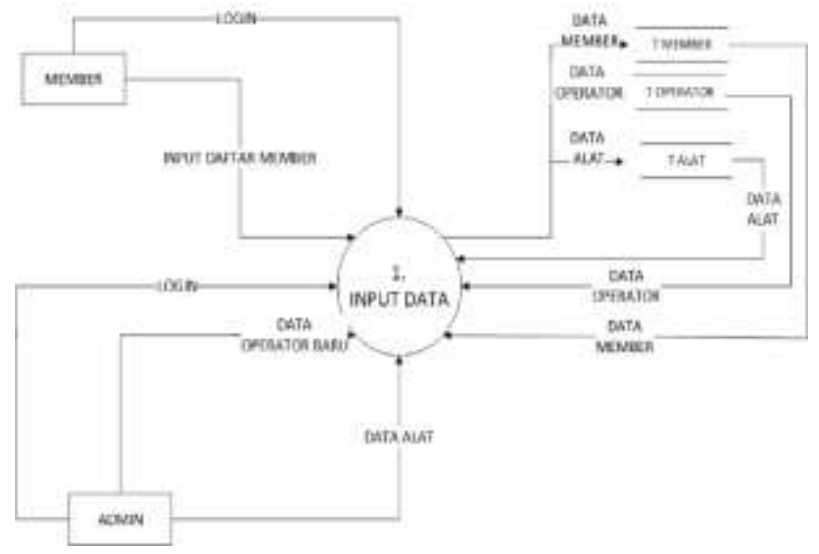

Gambar 2 DFD Level 1 Proses Input Data

Penjelasan dari gambar DFD level 1 proses input data:

- Member menginput data member ke dalam proses yang selanjutnya disimpan dalam tabel database member.

- Admin menginput data operator baru ke dalam proses yang selanjutnya disimpan dalam database operator, selanjutnya admin juga mengmasukkan data alat yang tersimpan dalam tabel database alat.

\subsubsection{DFD Level 1 Proses Transaksi}

Dalam DFD level 1 proses transaksi melibatkan 2 entitas yaitu admin dan member. Pada level ini terdapat tambahan 4 tabel database baru yang terlibat yaitu tabel peminjaman, pengembalian, keranjang, dan transaksi. Karena pada proses transaksi ini terdapat 2 proses utama yaitu peminjaman dan pengembalian alat laboratorium. Untuk lebih jelasnya dapat dilihat dalam gambar 3 .

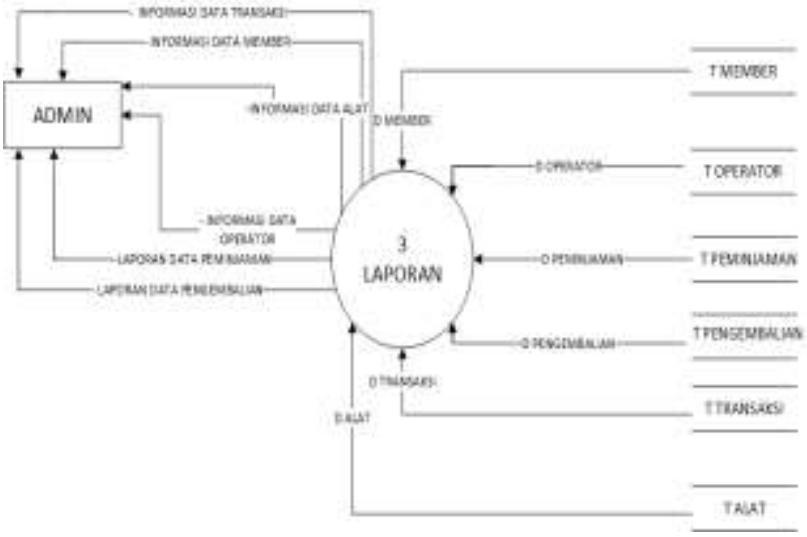

Gambar 3 DFD Level 1 Proses Transaksi

\subsubsection{DFD Level 1 Proses Laporan}

Dalam DFD level 1 proses laporan merupakan output yang dihasilkan dari proses pengolahan beberapa data antara lain data member, data operator, data alat, data peminjaman, data pengembalian, dan data transaksi. Sedangkan laporan yang dihasilkan antara lain laporan member, laporan operator, laporan alat, laporan peminjaman, laporan pengembalian dan laporan transaksi. Berikut disajikan gambar DFD level 1 proses laporan.

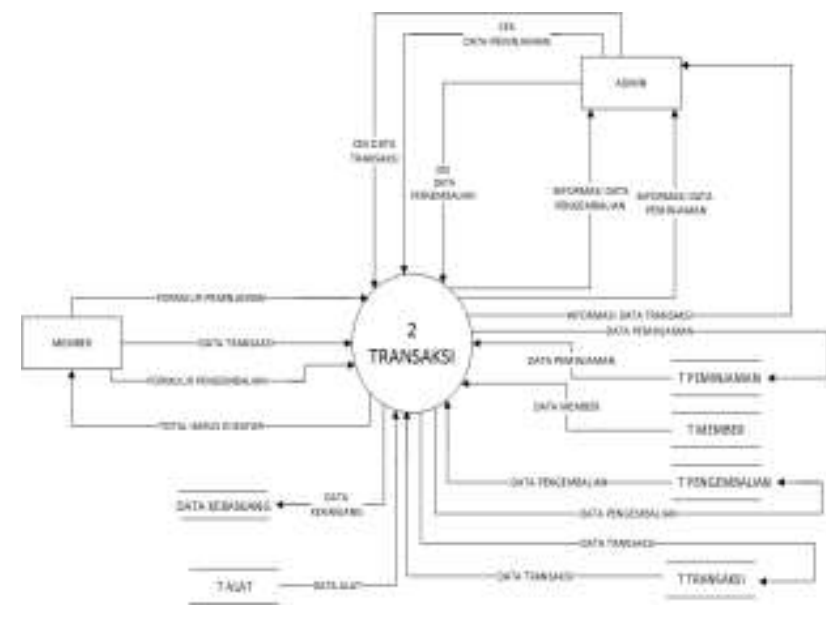

Gambar 4 DFD Level 1 Proses Transaksi Untuk DFD level 2, pada dasarnya prosesnya hanya diturunkan dari DFD dari semua proses yang ada pada DFD Level 1 pada masingmasing proses. Nantinya akan mengikuti jumlah proses yang ada pada DFD Level 1.

\section{Implementasi Dan Pengujian}

\subsection{Software Dan Hardware}

Dalam pembuatan aplikasi penyewaan alat laboratorium FPIK, perangkat keras yang dibutuhkan antara lain: 
- Laptop dengan spesifikasi Processor: Intel(R) Core (TM) i3 CPU M 370 @ $2.40 \mathrm{GHz}$

- Kapasitas RAM sebesar 2048 MB

- Harddisk 500 GB

Sedangkan perangkat lunak yang dibutuhkan yaitu:

- Sistem operasi Windows 7

- Browser Mozilla Firefox

- PHP

- XAMPP

- MySQL

- Adobe Photoshop

- Dreamweaver

\subsection{Implementasi}

\subsubsection{Tampilan Halaman Utama (Home)}

Halaman ini merupakan bagian yang dapat diakses oleh semua pengunjung web tanpa harus melakukan login terlebih dahulu. Pada halaman ini pengunjung dapat melihat peralatan apa saja yang dapat disewa beserta biaya sewanya pada laboratorium FPIK. Selain itu juga pada halaman ini pengunjung dapat melihat informasi mengenai tatacara peminjaman dan pengembalian alat serta denda yang harus dibayar jika terlambat melakukan pengembalian. Adapula menu login yang disediakan pada halaman ini bagi pengunjung yang ingin melakukan pendaftaran sebagai member. Karena alat laboratorium FPIK hanya dapat dipinjam jika pengunjung telah mendaftar sebagai member terlebih dahulu. Gambar 5 merupakan tampilan awal website aplikasi peminjaman peralatan laboratorium FPIK.

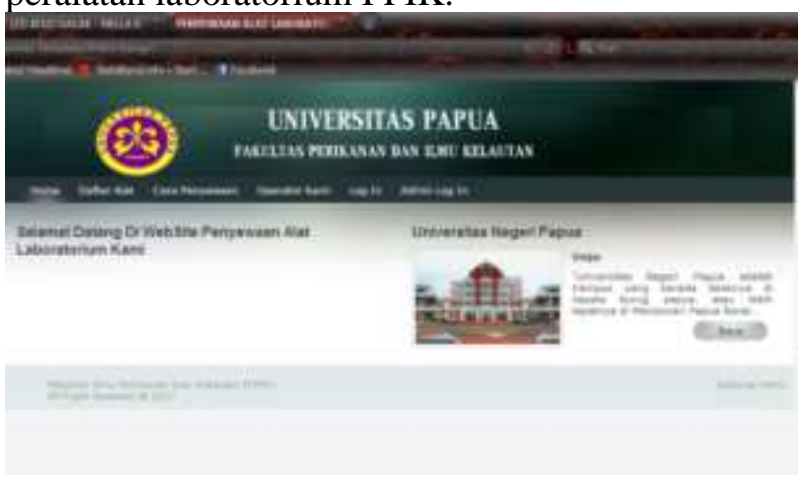

Gambar 5 Tampilan Halaman Utama

\subsubsection{Tampilan Halaman Admin}

Pada halaman admin ini terdapat beberapa menu antara lain cek daftar member, operator, alat, peminjaman, pengembalian, dan data transaksi (dapat dilihat pada Gambar 6). Untuk daftar peminjaman dan pengembalian dibuatkan notifikasi yaitu berupa sebuah tanda merah dan jumlah notifikasinya. Hal ini bertujuan untuk memudahkan admin dalam mengecek halaman website apakah ada transaksi peminjaman dan pengembalian yang baru dilakukan oleh member.

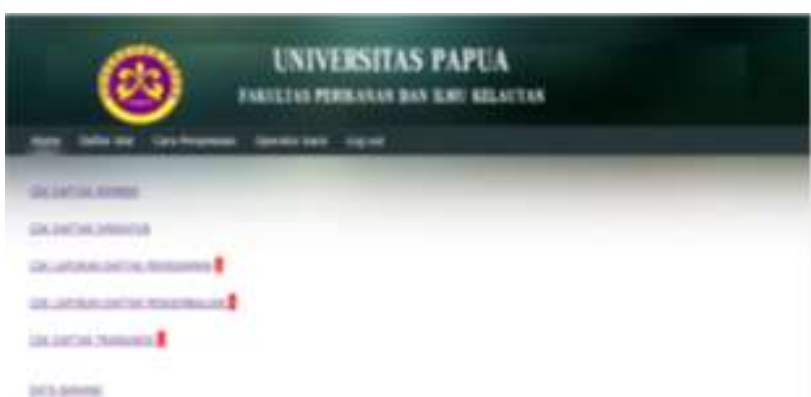

Gambar 6 Tampilan Halaman Admin

Pada transaksi peminjaman, notifikasi akan terkirim jika member telah melakukan proses pembayaran pada Bank yang telah ditentukan sebelumnya oleh pihak laboratorium. Jika proses pembayaran telah dilakukan, maka member harus mengupload bukti pembayaran transaksi di ATM/Bank pada form yang telah disediakan dalam aplikasi ini yaitu pada halaman member. Maka dengan sendirinya notifikasinya akan masuk ke dalam daftar peminjaman yang berada pada halaman admin (Gambar 7). Jika bukti pembayaran telah divalidasi kebenarannya oleh admin maka admin dapat mengklik pada tulisan terima yang terdapat pada form peminjaman alat ini.

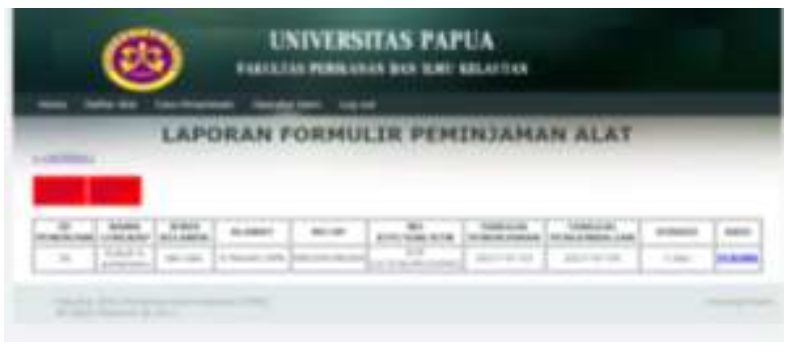

Gambar 7 Formulir Peminjaman Alat

Jika pembayaran telah diterima maka operator akan mengantarkan alat laboratorium yang dipinjam kepada member dan sekaligus mengambil Kartu Tanda Penduduk (KTP) asli member sebagai jaminan saat peminjaman alat. Dan KTP ini akan dikembalikan oleh operator saat mengambil alat laboratorium. Selain itu operator juga membawa formulir peminjaman alat laboratorium yang akan diberikan kepada 
member. Formulir ini dicetak dari menu yang tersedia pada menu peminjaman alat pada akun admin (dapat dilihat pada Gambar 8)

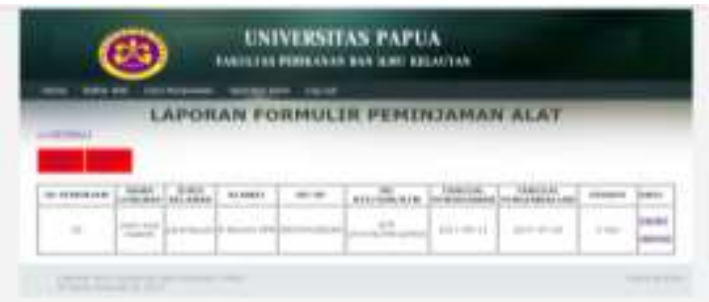

Gambar 8 Formulir Peminjaman Alat

Sedangkan untuk proses pengembalian alat laboratorium yang dilakukan admin hanyalah mengecek notifikasi pada link cek daftar pengembalian. Jika ada formulir pengembalian alat yang diajukan oleh member maka admin hanya tinggal menyetujui proses pengembalian dengan cara mengklik pada tulisan terima (dapat dilihat pada Gambar 9), maka dengan sendirinya pada transaksi admin dapat mencetak formulir pengembalian alat laboratorium yang akan dibawa oleh operator saat mengambil alat sesuai dengan alamat member yang tertera pada formulir pengembalian tersebut. Pada formulir tersebut juga terdapat nama petugas operator yang mengambil alat laboratorium, hal ini untuk meminimalisir kesalahan yang terjadi saat proses pengembalian alat.

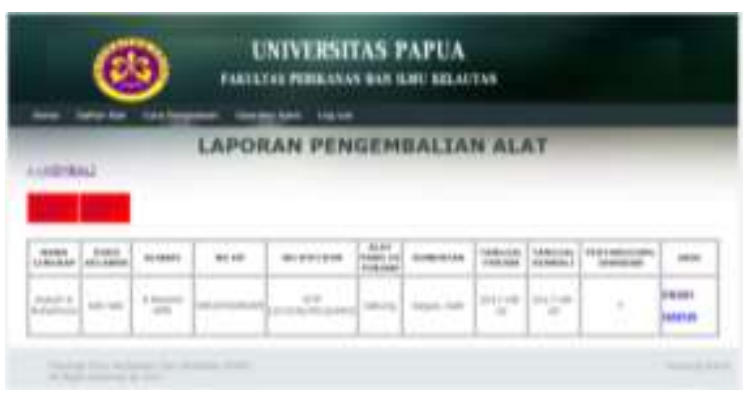

Gambar 9. Form Cetak formulir pengembalian alat

Fitur lain yang disediakan pada halaman admin yaitu cek data transaksi (dapat dilihat pada Gambar 10). Pada link ini admin dapat mengecek daftar alat yang telah dikirim, bahkan juga daftar denda member.

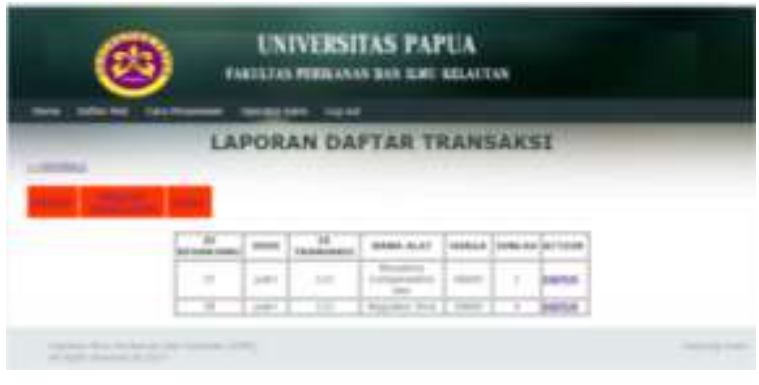

Gambar 10. Form Daftar Transaksi

\subsubsection{Tampilan Halaman Member}

Pada halaman member terdapat menu mengenai daftar alat laboratorium, cara penyewaan/peminjaman, cara pengembalian, daftar operator dan log out.

Pada menu daftar alat laboratorium (Gambar 11) memuat tampilan tentang daftar alat yang dimiliki laboratorium FPIK beserta biaya sewa dan stok alat yang tersedia, dimana stok ini akan mengikuti transaksi peminjaman dan pengembalian yang terjadi.

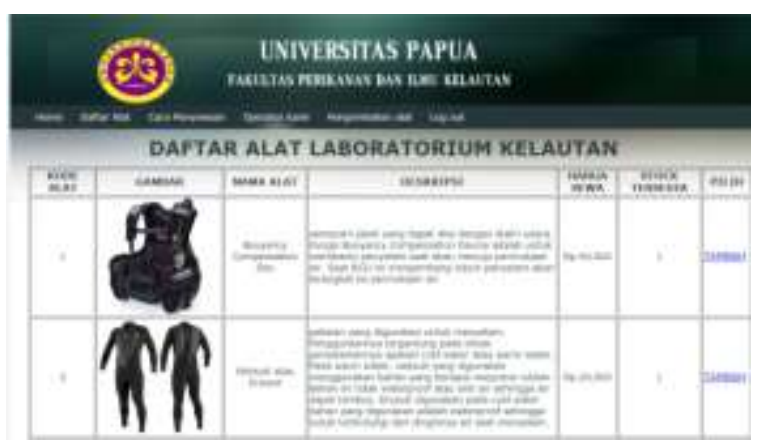

Gambar 11. Menu Daftar Alat Laboratorium

Di setiap alat laboratorium dilengkapi dengan fasilitas untuk menambahkan secara langsung alat yang ingin disewa oleh member. Maka secara otomatis barang yang dipilih akan masuk ke dalam keranjang penyewaan (dapat dilihat pada Gambar 12).

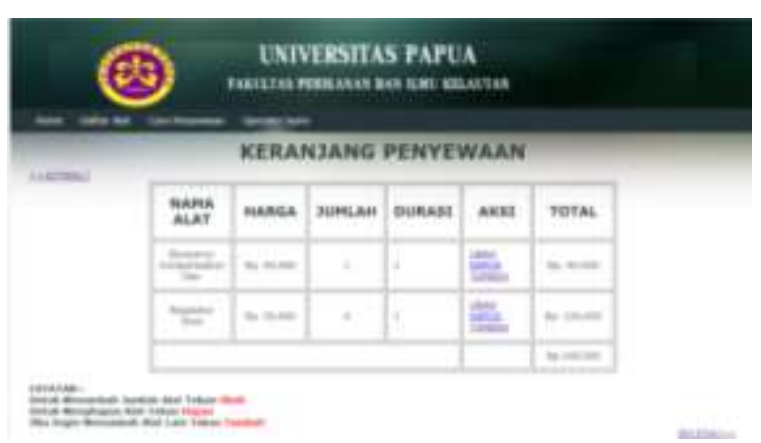

Gambar 12. Keranjang Penyewaan 
Selanjutnya member dapat melanjutkan dengan mengklik kata selesai di sebelah kanan bawah, dan secara otomatis akan muncul tampilan jumlah yang harus dibayar (Gambar 13).

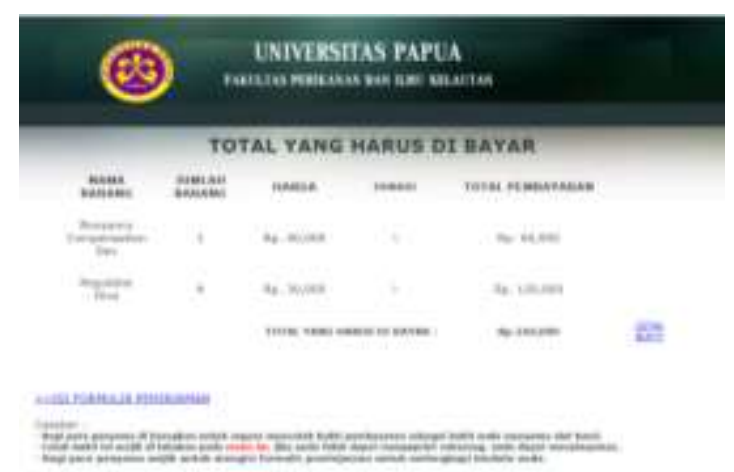

Gambar 13 Keranjang Penyewaan

Setelah itu member dapat mengklik tulisan isi formulir peminjaman yang akan menampilkan sebuah form yang harus diisi oleh member (tampilan pada Gambar 14)

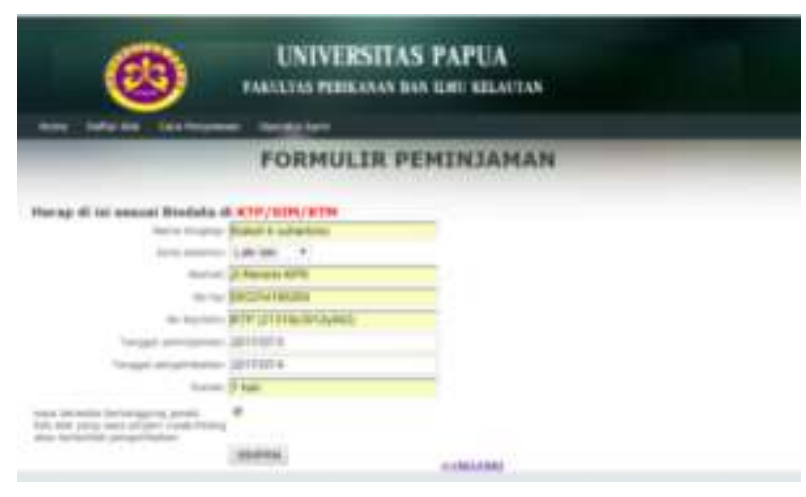

Gambar 14 Formulir Peminjaman Alat

Pada form peminjaman alat ini, member mengisi data diri serta tanggal peminjaman dan juga tanggal pengembalian alat. Begitupun saat member akan mengembalikan alat laboratorium yang dipinjam harus mengisi sebuah form pengembalian alat. Pada saat form tersebut dikirim maka petugas dari pihak FPIK akan datang ke rumah peminjam untuk mengambil alat laboratorium yang dipinjam termasuk mengembalikan kartu jaminan yang diberikan saat member melakukan proses peminjaman berupa Kartu Tanda Penduduk (KTP).

\subsection{Pengujian}

Teknik pengujian yang dilakukan terhadap aplikasi peminjaman alat laboratorium ini menggunakan metode blackbox, yaitu dengan menjalankan semua fitur yang ada di sistem ini dan kemudian dilihat apakah hasil dari fungsi-fungsi tersebut berhasil atau tidak. Hasil dari pengujian terhadap sistem dapat dilihat pada Tabel 4.1.

Dari hasil pengujian blackbox yang dilakukan, dapat disimpulkan bahwa semua fungsi yang ada dalam aplikasi ini semuanya berfungsi dengan baik dan sesuai dengan hasil perancangan sistem yang telah dibuat.

\section{Penutup}

\subsection{Kesimpulan}

Dari hasil penelitian, perancangan dan implementasi yang penyusun lakukan maka ada beberapa kesimpulan yang dapat di kemukakan yaitu sebagai berikut:

1. Dengan adanya aplikasi Penyewaan Alat Laboratorium Fakultas Ilmu Kelautan Dan Perikanan Universitas Papua ini dapat menjadi solusi bagi pihak Laboratorium untuk memberikan pelayanan berupa aplikasi dibanding dengan sebelumnya yang masih menggunakan teknik pencatatan.

2. Hasil pengujian secara blackbox menunjukkan bahwa aplikasi yang dibuat telah berfungsi dengan baik sesuai dengan perancangan yang telah dibuat sebelumnya.

\subsection{Saran}

Adapun beberapa saran yang dapat diberikan untuk pengembangan aplikasi ini ke depannya antara lain:

1. Dalam aplikasi ini perlu ditambahkan sebuah notifikasi jika ada member yang ingin melakukan penyewaan peralatan laboratorium FPIK, sehingga memudahkan pihak laboratorium dalam melakukan pengecekan.

2. Menambahkan fitur untuk menghitung denda total perhari secara otomatis apabila ada member yang terlambat melakukan pengembalian alat laboratorium maupun juga terdapat kerusakan pada alat laboratorium yang dipinjam oleh member. 
Tabel 4.1 Hasil Pengujian Blackbox Aplikasi

\begin{tabular}{|c|c|c|c|}
\hline Tes & Prosedur yang dijalankan & Hasil yang diharapkan & Hasil \\
\hline $\begin{array}{l}\text { Daftar Member } \\
\text { baru }\end{array}$ & $\begin{array}{l}\text { Pada menu home piih Lof In lalu } \\
\text { pilih belum punya akun daftar } \\
\text { disini }\end{array}$ & $\begin{array}{l}\text { Member melakukan pendaftaran } \\
\text { dengan mengisi biodata. }\end{array}$ & Berhasil \\
\hline $\begin{array}{l}\text { Member } \\
\text { melakukan Log } \\
\text { In }\end{array}$ & Pada menu home pilih Log in & $\begin{array}{l}\text { Masukan } \\
\text { username }\end{array}$ password dan & Berhasil \\
\hline $\begin{array}{l}\text { Member } \\
\text { memilih alat }\end{array}$ & $\begin{array}{l}\text { Setelah } \log \text { In pilih menu daftar alat } \\
\text { lab, lalu kemudian pilih alat yang } \\
\text { akan ditambahkan ke dalam } \\
\text { keranjang penyewaan }\end{array}$ & $\begin{array}{l}\text { Admin berhasil menambahkan } \\
\text { alat yang akan disewa kedalam } \\
\text { keranjang penyewaan }\end{array}$ & Berhasil \\
\hline $\begin{array}{l}\text { Daftar keranjang } \\
\text { member }\end{array}$ & $\begin{array}{l}\text { Setelah member melakukan } \\
\text { pemilihan alat otomatis data akan } \\
\text { masuk dalam keranjang penyewaan. }\end{array}$ & $\begin{array}{l}\text { Pada menu ini member meilihat } \\
\text { jumlah daftar alat yang disewakan } \\
\text { serta pentotalan biayanya yang } \\
\text { dikeluarkan, dan dapat merubah } \\
\text { jumlah alat yang akan disewa, } \\
\text { atau dapat mengahapus alat yang } \\
\text { tidak jadi disewa sebelum } \\
\text { disetujui }\end{array}$ & Berhasil \\
\hline $\begin{array}{l}\text { Total yang harus } \\
\text { dibayar }\end{array}$ & $\begin{array}{l}\text { Setelah member mengklik tombol } \\
\text { selesai pada menu keranjang } \\
\text { penyewaan maka akan secara } \\
\text { otomatis menuju menu total yang } \\
\text { harus dibayar. }\end{array}$ & $\begin{array}{l}\text { Pada menu ini member akan } \\
\text { melihat total biaya yang harus } \\
\text { dibayarkan. }\end{array}$ & Berhasil \\
\hline Print cetak bukti & $\begin{array}{l}\text { Pada menu total yang harus dibayar, } \\
\text { pilih menu Cetak Bukti }\end{array}$ & $\begin{array}{l}\text { Member melakukan print untuk } \\
\text { bukti saat bahwa member } \\
\text { melakukan transaksi }\end{array}$ & Berhasil \\
\hline $\begin{array}{l}\text { Member mengisi } \\
\text { formulir } \\
\text { peminjaman }\end{array}$ & $\begin{array}{l}\text { Pada menu total yang harus dibayar, } \\
\text { pilih menu mengisi formulir } \\
\text { peminjaman }\end{array}$ & 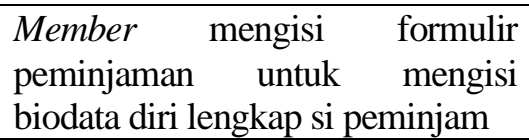 & Berhasil \\
\hline $\begin{array}{l}\text { Member mengisi } \\
\text { Formulir } \\
\text { Pengembalian }\end{array}$ & $\begin{array}{l}\text { Pada menu awal, pilih menu } \\
\text { pengemablian alat. }\end{array}$ & $\begin{array}{l}\text { Member mengisi formulir } \\
\text { pengembalian untuk mengisi } \\
\text { biodata diri lengkap si peminjam, } \\
\text { dan memberikan penilaian teradap } \\
\text { alat yang disewakan }\end{array}$ & Berhasil \\
\hline $\begin{array}{l}\text { Member } \\
\text { melakukan Log } \\
\text { out }\end{array}$ & Pada menu awal, pilih menu log out & $\begin{array}{l}\text { Member akan otomatis keluar dari } \\
\text { menu member }\end{array}$ & Berhasil \\
\hline
\end{tabular}

\section{Referensi}

Al Bahra Bin Ladjamudin, 2005, Pemrograman Delphi 7. Yogyakarta: Bunafit Komputer.

Andi, 2007, Belajar Mudah Desain Web Dengan Macromedia Dreamweaver dan Adobe Photoshop. Yogyakarta: Andi Offset.

Andi, 2008, Belajar PHP MYSQL. Yogyakarta: Andi Offset.

Axmark, Monty 1979. Pemrograman Web dengan PHP dan MySQL. Jakarta: Universitas Budi Luhur.

Dwiartabayu 2001, Analisis dan Desain Sistem Informasi. Jakarta: Universitas Budi Luhur.

Harun Amin, 2013, Perancangan Aplikasi EComerce Pada Toko Oleh-Oleh Khas Makasar "kota daeng”. Makassar: STMIK Dipanegara Makassar.

Hidayat, Rahmat. 2010.Cara Praktis Membangun Website Gratis. Jakarta: PT. Elex Media Komputindo. 